\title{
Extraction, Characterization and Utilization of Fish Protein Concentrate
}

\author{
Mahesh C. Phadtare ${ }^{1}$, Rahul C. Ranveer ${ }^{1}$, Nikheel B. Rathod ${ }^{1, *} \mathbb{D}$, Shrikant T. \\ Sharangdhar ${ }^{2}$, Shrikant B. Swami ${ }^{1}$, Vivek R. Vartak ${ }^{1}$, Jayappa M. Koli ${ }^{2}$, Surendra B. \\ Patange $^{1}$
}

${ }^{1}$ DBSKKV, Post Graduate Institute of Post Harvest Management, Killa-Roha, Dist. Raigad, Dapoli, India.

${ }^{2}$ DBSKKV, College of Fisheries, Department of Fish Processing Technology and Microbiology, Shirgaon, Ratnagiri, Dapoli, India.

\section{How to cite}

Phadtare, M.C., Ranveer, R.C., Rathod, N.B., Sharangdhar, S.T., Swami, S.B., Vartak, V.R., Koli, J.M., Pujari, K.H. (2021). Extraction, Characterization and Utilization of Fish Protein Concentrate. Aquatic Food Studies, 1(2), AFS47. https://doi.org/10.4194/AFS47

\section{Article History}

Received 02 October 2021

Accepted 05 November 2021

First Online 09 November 2021

\section{Corresponding Author \\ Tel.: +919946346830 \\ E-mail: \\ nikheelrathod310587@gmail.com}

\section{Keywords}

Fish protein concentrate

Pink perch

Fish fingers

Functional properties

Biochemical changes

\begin{abstract}
Progress in investigation for extraction of fish protein concentrate (FPC) by different solvents (acetone, isopropyl alcohol and hexane: ethanol azeotropic mixture as Canadian, British and Indian method) of pink perch (Nemipterus spp.) analyzed for their functional properties and further utilized in developing value added product. FPC extracted by isopropyl alcohol was superior with significantly $(P<0.05)$ highest protein, lowest moisture and fat content. Significantly $(P<0.05)$ superior viscosity $(118.37 \mathrm{cP})$, Protein solubility (84.40\%), Emulsification capacity (68.53\%), Emulsification stability (60.92\%), Foaming capacity $(140.01 \%)$, Foaming stability $(121.70 \%)$ and Water holding capacity $(25.35 \mathrm{~mL} / \mathrm{g})$ for isopropyl alcohol compared with other solvents. Due to typical fishy odor fish meat replaced with $\operatorname{FPC}(0,5,10,15$ and $20 \%)$ in fish finger formulation with FPC incorporation at $10 \%$ levels were most acceptable. Strong linearity $\left(R^{2}\right)$ for changes biochemical values $\left(R^{2}>0.96\right)$ and microbiological values $\left(R^{2}=0.9705\right)$ were found. Sensory evaluation had a negative correlation $\left(R^{2}>0.814\right)$ during storage suggesting shelf life of 11 days. Suggesting utilization of low value fishes for extraction of high quality proteins and their application for development of novel foods.
\end{abstract}

\section{Introduction}

Fish consumption has increased worldwide due to high nutritive value with several health benefits making fish an irreplaceable source of animal protein, affordable to the public and majority contribution in global food trade (Rathod et al., 2021). Rapid urbanization has led a change in eating habits, with more and more population preferring "Ready-To-Cook and Ready-To-Eat" snack food, making it a favorite choice (Xavier et al., 2018).

Fish protein concentrate (FPC) is colorless, tasteless and odorless powder; containing high protein, essential amino acids and nutrients concentrated than fresh fish produced hygienically for human consumption, (FAO, 2006). It was used as food supplement/additive/fortify to improve human health, provide nutrition and prevent disease (Shaviklo et al., 2011; Cercel et al., 2016). Incorporating foods with aquatic proteins provides avenues for development of innovative value added products, several successful applications successfully developed as mayonnaise, Ice cream, Spaghetti and pasta, Macaroni, Wheat flour bread, Indian bread, and Biscuits.

Thread fin bream (Nemipterus spp.) commonly known as pink perch, spread widely along the tropical and subtropical region of Indo-west pacific, a major bycatch of the shrimp fishery in coastal waters of India. 
Pink perch used to develop good quality products due to its light colored meat, low fat and plenty of availability. Battered and breaded products are convenience food, appreciated worldwide due to ease of preparation, stable shelf life, higher nutritional value with crunchy outside and juicy interior. Fish fingers is popular batter and breaded snack food consumed worldwide by all age groups (Cakli et al., 2005).

An attempt has been made to extract FPC from low cost fish pink perch by Canadian, British and Indian method, with their functional characterization and inclusion in fish fingers to improve physiochemical, nutritional and sensory quality.

\section{Materials and Methods}

\section{Raw Materials}

Pink perch (Nemipterus spp.) fishes procured, transported in iced condition (1:1) to the laboratory using insulated boxes. Fish samples were washed with potable water, beheaded by cutting head off, gutted manually, dressed, minced and stored at $-18^{\circ} \mathrm{C}$ till further use.

\section{Chemicals and Other}

All media and chemicals used in the study were either of bacteriological or analytical grades, purchased from Himedia Pvt. Ltd., Mumbai. Other materials used for product development were of food-grade and bought locally.

\section{Preparation of Fish Protein Concentrated (FPC)}

FPC prepared using three different methods i.e., Canadian, British and Indian methods employing using ethanol, isopropyl alcohol and azeotropic mixture (Hexane: ethanol) as solvents described by Govindan (1985) with slight changes as mentioned below.

\section{British Method}

Equal proportion of cooked meat minced with an equal weight of acetone for $45 \mathrm{~min}$. filtered, pressed and vacuum dried to remove traces. Further refluxed with an equal weight of $90 \%$ ethanol for $45 \mathrm{~min}$., followed by cooling, filtering, and drying. The dried mass again deodorized and defatted with ethanol filtered, heated under vacuum to remove traces of solvent, milled and packed in airtight conditions.

\section{Canadian Method}

Groundfish muscle suspended in enough water acidified with phosphoric acid having $\mathrm{pH} 5.5$, heated for $30 \mathrm{~min}$. at $70-80^{\circ} \mathrm{C}$ with constant stirring, the mass filtered and repeatedly washed with hot water until deodorized. The deodorized, water free residue further suspended in double volume of isopropyl alcohol and refluxed for $15 \mathrm{~min}$. further mass is heated under vacuum to remove traces of solvent, followed by cooling, milling and packaged in airtight conditions.

\section{Indian Method}

Fish meat cooked with an equal volume of acetic acid $(0.5 \%)$ for 45 min., cooled allowed to settle and floating oil removed, the slurry filtered using canvas bags and pressed. Press cake extracted with ethanol (deodorize), second extraction with an azeotropic mixture of Hexane: ethanol (33.2 \%) for 45 min. filtered, pressed and vacuum dried. Steam stripped to remove the last traces of ethanol residues, followed by drying, cooling, milling and packaged in airtight conditions.

\section{Determination of Functional properties of FPC}

Viscosity

Viscosity measured using the procedure described by Cho et al., (2006). Briefly 6.67g FPC sample dissolved in $100 \mathrm{~mL}$ distilled water and heated at $60^{\circ} \mathrm{C}$. The viscosity ( $\mathrm{CP}$ ) of the solution recorded using Brookfield viscometer (Model DV - E Brookfield, USA) at $40 \pm 1^{\circ} \mathrm{C}$.

\section{Protein Solubility}

To evaluate protein solubility about $500 \mathrm{mg}$ of FPC sample accurately weighed and dispersed in $50 \mathrm{~mL}$ of $0.1 \mathrm{M} \mathrm{NaCl}$ at $\mathrm{pH}$ 7. The solution stirred on a magnetic stirrer for $1 \mathrm{~h}$. and centrifuged 10,000 rpm for $30 \mathrm{~min}$. (Hoyle and Merritt 1994). The supernatant was analyzed for nitrogen by the micro-Kjeldhal's method (AOAC, 2005). The Protein Solubility calculated as,

Protein solubility $(\%)=\frac{\text { Supernatant NC }(\mathrm{mg})}{\text { Sample NC }(\mathrm{mg})} \times 100$

(NC: Nitrogen Concentration)

\section{Emulsifying Capacity and Stability}

FPC sample ( $1.8 \mathrm{~g}$ ) added to $25 \mathrm{~mL}$ of distilled water and dispersed in a homogenizer. Added with, corn oil $(12.5 \mathrm{~mL})$ and homogenized and centrifuged at 5200 rpm for 5 min. (Butt and Batool 2010). Emulsifying capacity calculated as,

$$
\text { EC }(\%)=\frac{\text { Height of emulsified layer }}{\text { Height of total contents of tube }} \times 100
$$

\section{(EC: Emulsifying Capacity)}

Emulsifying stability was determined in a similar way to that of emulsion capacity except that the emulsion was initially heated in a water bath at $85^{\circ} \mathrm{C}$ for $30 \mathrm{~min}$. and subsequently cooled to $25^{\circ} \mathrm{C}$ prior to 
centrifugation (Butt and Batool 2010).

$$
\mathrm{ES}(\%)=\frac{\text { Height of emulsified layer after heating }}{\text { Height of total contents of tube }} \times 100
$$

(ES: Emulsifying Stability)

\section{Foaming Capacity and Stability}

The FPC ( $1 \mathrm{~g})$ added to $100 \mathrm{~mL}$ distilled water and homogenized. The mixture carefully transferred into a $250 \mathrm{~mL}$ calibrated beaker for volume measurement. The foam calculated as the volume of mixture after blending compared with the original volume. The foaming stability was the ratio of the foam capacity after $30 \mathrm{~min}$. to the original foam capacity (Miller and Goninger, 1976).

\section{Water Holding Capacity}

The water holding capacity (WHC) determined using the centrifugation method of Diniz and Martin, (1997). In detail, FPC samples (0.5 g) dissolved in $20 \mathrm{~mL}$ distilled water and dispersed with a vortex mixer for 30 sec. The dispersion allowed to stand at room temperature for 6 h., and centrifuged at $2800 \mathrm{rpm}$ for 30 min. The supernatant was filtered with Whatman No. 1 filter paper and the volume recovered measured. The difference between the initial volume of distilled water added to the protein sample and the volume of the supernatant determined, and the results reported as $\mathrm{mL}$ of water absorbed per $\mathrm{g}$ of the FPC sample.

\section{Development of High Protein Fish Fingers}

Standardized recipe of Vanitha, (2011) used for development of fish fingers containing $1 \%$ wheat flour, $1.5 \%$ salt, $1 \%$ chilli powder, $0.24 \%$ cumin seed, $0.24 \%$ onion paste, $0.24 \%$ pepper powder, $0.02 \%$ ginger paste and $0.02 \%$ sodium tripolyphosphate (STPP) and incorporated with derived FPC (Canadian method) at different proportion $\mathrm{T}_{1}-0 \%, \mathrm{~T}_{2}-5 \%, \mathrm{~T}_{3}-10 \%, \mathrm{~T}_{4}-15 \%$ and $\mathrm{T}_{5}-20 \%$ respectively to alter the percentage of fish mince. The fingers were coated in standardized batter mix (Pagarkar et al., 2012) containing $77.5 \%$ refined wheat flour, $9.7 \%$ corn flour, $9.7 \%$ bengal gram flour, $1.20 \%$ salt, $0.47 \%$ STPP, $0.47 \%$ turmeric powder, $0.96 \%$ carboxy methylcellulose (CMC) which were mixed with water in the ratio of $1: 2$ and was blended to homogeneity. After the batter coating, it was covered with bread crumbs, they were flash-fried at $180^{\circ} \mathrm{C}$ for 30 sec.

\section{Storage Stability}

The prepared fish fingers were air packed into polypropylene bags and stored at $4 \pm 1^{\circ} \mathrm{C}$ for a period of 15 days analyzed for sensory, biochemical and microbial parameters every alternate day.

\section{Proximate Composition}

The FPC and Fish fingers were analyzed for proximate composition i.e. moisture, lipid, protein, and ash (AOAC, 2005).

\section{Biochemical Analysis}

The sample (5 g) wsa homoginized with $45 \mathrm{~mL}$ distilled water and filtered using a filter paper and subjected to $\mathrm{pH}$ determination (AOAC, 2005). Peroxide value (PV) an excellent indicator of lipid rancidity, measured by titrimetric method and expressed as equivalent of $\mathrm{O}_{2} / \mathrm{kg}$ (AOAC, 2005), Free fatty acid (FFA) content evaluated, according to AOAC, (2005) and results expressed as percentage of oleic acid. Total volatile basic nitrogen (TVB-N) contents were determined by the procedure given by Beatty and Gibbons, (1936) using Conway micro-diffusion units and results were expressed in terms of nitrogen $\mathrm{mg} / 100 \mathrm{~g}$. TMA-N content was determined similarly as that of TVB$N$ exception in the procedure is that $1 \mathrm{~mL}$ of formaldehyde solution added to the sample and left for $10 \mathrm{~min}$. before the addition of potassium carbonate solution. The trimethylamine nitrogen (TMA-N) content expressed as mg per $100 \mathrm{~g}$ of the sample.

\section{Microbiological Analysis}

The product sample $(10 \mathrm{~g})$ aseptically homogenized with physiological saline $(0.85 \% \mathrm{NaCl}) 90 \mathrm{~mL}$ The homogenized sample was serially diluted to (1:10) in physiological saline as needed. Total plate count (TPC) was enumerated by spreading $(1 \mathrm{~mL})$ of homogenate on plate count agar and incubated at $35^{\circ} \mathrm{C}$ for $48 \mathrm{~h}$. For Escherichia coli, Tergitol-7 agar was used with incubation at $35^{\circ} \mathrm{C}$ for $24 \mathrm{~h}$. Staphylococcus aureus and Salmonella were estimated using Baird Parker and Bismuth Sulphate agar respectively followed by incubation at $35^{\circ} \mathrm{C}$ for $48 \mathrm{~h}$. Spore count was estimated using Dextrose tryptone agar AOAC (1995). After incubation plates showing typical colonies were counted and calculated by multiplying the number of counted colonies with reciprocal of dilution factor and depicted as $\log \mathrm{cfu} / \mathrm{g}$.

\section{Sensory Evaluation}

Sensory evaluation is considered as the best method to judge market acceptability of the product. FPC incorporated Fish finger was subjected to sensory analysis based on 9 point hedonic scale, with 9 (Like extremely) to 1 (dislike extremely) and 5 (being borderline of acceptability). Samples were deep fat fried in refined sunflower oil at $180^{\circ} \mathrm{C}$ for $3 \mathrm{~min}$. prior to sensory evaluation and were considered unacceptable for consumption when the average overall acceptability of samples scores below 5 (Pawar et al., 2019). 


\section{Statistical Evaluation}

Experiments were performed in triplicates (unless specified), results are reported as mean values \pm standard deviation (S.D.). Data were analyzed to test significant differences by applying a one-way analysis of variances (ANOVA) tools available in MS-Excel 2013. The significant difference was tested at $5 \%$ level of significances and were mentioned as $\mathrm{P}<0.05$ for significant difference. When significant $F$ was found, additional post-hoc tests with the least significant difference (LSD) test were performed (Snedecor and Cochran, 1967).

\section{Results and Discussion}

\section{Effect of Extraction Methods on Proximate Composition of FPC}

Proximate composition of FPC extracted from Pink perch fish by Canadian, British and Indian methods are presented in Table 1 different methods had a significant effect upon the proximate quality of FPC obtained. Significantly $(P<0.05)$ highest protein content was reported in FPC obtained by the Canadian method (92.56\%) extracted by using isopropyl alcohol, followed by Indian and British methods. Lowest moisture and fat content were recorded in the Canadian process $(4.61 \pm 0.03$ and $0.49 \pm 0.01 \%)$. Sathivel et al., (2003) reported that fat content was influenced by the extraction solvent rather than the extraction method, whereas ash content was not influenced by the extraction methods. The level of protein in the FPC sample is comparable to the protein powder extracted from Saithe (Pollachius virens) 93.5\% (Shaviklo et al., 2012) and Red cod (Pseudophycis bachus) $88.75 \%$ (Desai et al., 2018).

\section{Effect of Extraction Methods on Functional Properties of FPC}

Functional properties are those which affect the food systems during processing. The different extraction methods had a significant impact on the functional properties of FPC, which are depicted in Figure 1. The results of functional properties are lower in comparison to hydrolyzed proteins obtained due to the lower degree of hydrolysis in protein concentrates.

Table 1. Proximate composition of FPC extracted by using different methods

\begin{tabular}{lccc}
\hline Constituents (\%) & Canadian method & British method & Indian method \\
\hline Moisture & $4.61 \pm 0.18^{\mathrm{c}}$ & $9.63 \pm 0.24^{\mathrm{a}}$ & $8.06 \pm 0.12^{\mathrm{b}}$ \\
Protein & $92.56 \pm 0.44^{\mathrm{a}}$ & $87.34 \pm 0.36^{\mathrm{c}}$ & $89.05 \pm 0.17^{\mathrm{b}}$ \\
Fat & $0.49 \pm 0.05^{\mathrm{c}}$ & $1.01 \pm 0.07^{\mathrm{a}}$ & $0.72 \pm 0.08^{\mathrm{b}}$ \\
Ash & $2.31 \pm 0.14^{\mathrm{a}}$ & $0.72 \pm 0.05^{\mathrm{b}}$ & $2.17 \pm 0.07^{\mathrm{a}}$ \\
\hline
\end{tabular}

Each value is represented as the mean $\pm S D$ of $n=7$.

Values with different letters within the same row are significantly different at $\mathrm{P}<0.05$ by LSD

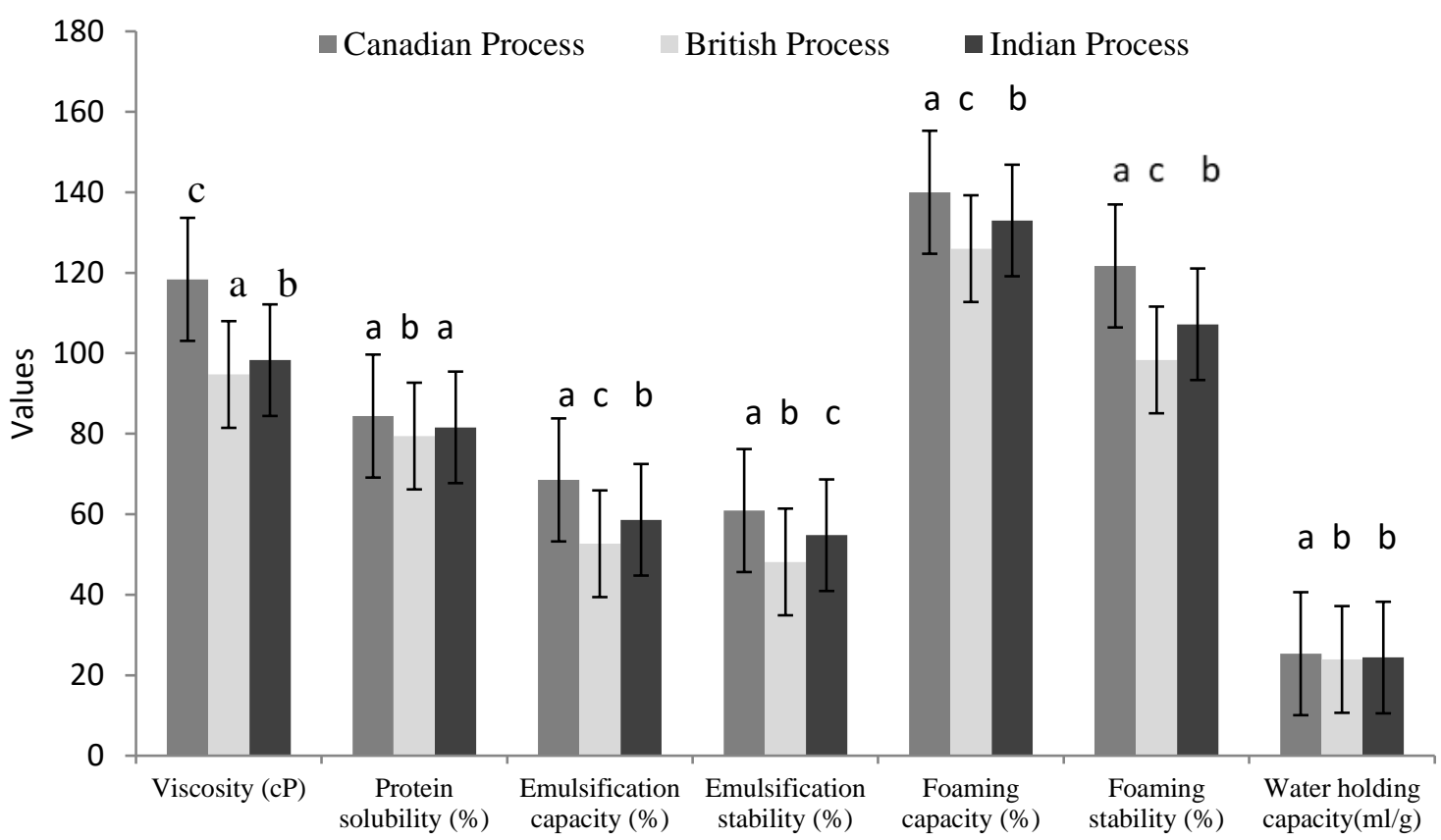

Functional Properties

Figure 1. Functional properties of FPC extracted by using different methods from Pink perch fish (Nemipterus japonicus). Values with different letters within the samples are significantly different at $\mathrm{P}<0.05$ by LSD 


\section{Viscosity}

The highest viscosity recorded in FPC extracted by the Canadian method than British and Indian respectively. Lower viscosity of FPC in the British and Indian methods may be attributed to extraction carried at high temperatures leading to denaturation of proteins (Shaviklo et al., 2012). Viscosity is affected by physical (molecular weight, size, shape, fractional ratio, and axial ratio) and functional (hydration) properties of protein (Bragadottir et al., 2007).

\section{Protein Solubility}

Protein solubility is one of the most important functional properties of proteins impacting emulsification and foaming properties deciding their utilization in food systems influenced by $\mathrm{pH}$ with an increase in solubility over $\mathrm{pH}$ 5. Different methods using various solvents and temperature impact on the quality of FPC as depicted in Figure 1. Maximum protein solubility was found in FPC extracted by Canadian, followed by Indian and British methods respectively. Increase in temperature of extraction, drastically reduced protein solubility of FPC. The results are lower than the reported solubility of fish protein hydrolysate, indicating low food applications and comparable levels with results of Naqash and Nazeer (2013). Solubility of pink perch protein may be the effect of increased denaturation or coagulation of proteins in FPC due to elevated extraction temperatures significantly $(P<0.05)$ decreased the solubility of proteins. Charges on proteins determining their solubility, usage of different acids and solvents at different temperatures increasing hydrophobicity leading to low protein-protein interaction, resulting in low solubility of FPC in comparison to fish protein hydrolysates (Naqash and Nazeer, 2013).

\section{Emulsifying Capacity (EC) and Stability (ES)}

Emulsification capacity and stability is mainly used to measure the ability of proteins to foam and stabilize emulsions. The EC and ES of FPC extracted by Canadian, Indian and British processes is depicted in Figure 1. The method of extraction significantly impacted upon the EC and ES $(P<0.05)$. It was observed that emulsification properties are directly proportional to protein content and related to a surface property of protein i.e., to adsorb the newly formed oil droplets during homogenization and prevent their coalescence. The proteins in FPC are mostly hydrophobic as compared to FPH (Hassan et al., 2018), rendering them lower EC and ES correlated to hydrophilic and hydrophobic proportions, charges on amino acids and peptide length imparting emulsification characters to proteins $\mathrm{Yu}$ et al (2007). The reason for the low emulsifying property can be attributed to heating causing loss of hydrophilic behavior (Shaviklo et al., 2011) and denaturation of proteins

\section{Foaming Capacity (FC) and Stability (FS)}

Foaming properties are well known to influence the softening, refreshment and dispersing aromatic constituents in foods (Yoon et al., 2018) impacting taste. Different methods of FPC extraction are found to significantly $(P<0.05)$ impact the foaming properties which are directly related to bulk density of protein. High values for FC and FS of FPC samples as depicted in (Figure 1) suggesting higher bulk density of extracted protein. Foaming property of proteins is surface characterized related to the ability to form layers at different (air-water) interfaces, as emulsifying properties. The good foaming property is directly related to protein-peptide length and degree of hydrolysis in protein preparation (Hassan et al., 2018).

\section{Water Holding Capacity (WHC)}

Water holding capacity of proteins is largely impacted by water protein interaction, the ability of the protein to imbibe water and hold against gravitational force, protein extraction technique, extraction temperature and species variation (Yu et al., 2007; Huda et al.,2000). The WHC is significantly $(P<0.05)$ impacted by different methods of extraction as depicted in Figure 1. Results were found matching the proposed theories of $3 g$ water per gram of protein (Sikorski et al., 1981). The reason for low WHC capacity may be the effect of high protein solubility and denaturation of proteins causing a decrease in peptide size which is hydrophilic in nature Halim et al., (2016).

\section{Effect FPC Incorporation on Proximate Composition of Fish Fingers}

The FPC incorporation significantly $(P<0.05)$ decreased the moisture content while significantly $(P<0.05)$ increased protein, fat, and ash with the increase in FPC incorporation (Figure 2). The highest protein content was noted in fish fingers incorporated with $20 \%$ FPC (33.7 \%), whereas the fingers without FPC $\left(\mathrm{T}_{1}\right)$ (i.e. control sample) had only $20.75 \%$ protein, which is the effect FPC composition. Commercially FPC is added in many food products to enhance the protein content. The decrease in moisture content is associated with interaction among protein, polysaccharide and starch Desai et al., (2018). Fish finger incorporated with $20 \%$ FPC showed the maximum energy value, while the lowest energy value was found in the control sample. The main reason for this high energy may be contributed to the proteins added by incorporating FPC. Cercel et al., (2016) reported that the wheat flour dough added with $10 \%$ FPC improved the nutritional of bread significantly. Ibrahim (2009) developed salt biscuits supplemented with $5 \%$ FPC and reported $12.50 \%$ protein in the final product. Chari and Sreenivasan (1980) reported that 
supplementation of foods with FPC at $10 \%$ level was significant without any undesirable changes. Results illustrated that FPC can be incorporated in fish fingers having high protein and energy value.

\section{Effect FPC Incorporation on Organoleptic Quality of Fish Fingers}

To know the market acceptability, the prepared products were subjected to sensory analysis by a semitrained panel (Figure 3). The results showed that the sensory scores of fish finger containing $10 \% \mathrm{FPC}\left(\mathrm{T}_{3}\right)$ scored significantly $(P<0.05)$ higher score with respect to all sensory parameters. While a sample containing more than $10 \%$ FPC scored significantly $(P<0.05)$ lower sensory score with respect to texture and taste. The results of organoleptic quality demonstrated that the addition of $10 \%$ FPC $\left(\mathrm{T}_{3}\right)$ was most acceptable to the sensory panel so that it was used for further study.

\section{Effect of Storage on Biochemical Quality of Fish Fingers}

The biochemical parameters are one of the best means to estimate the shelf life of products. The results of biochemical analysis of FPC incorporated fish fingers

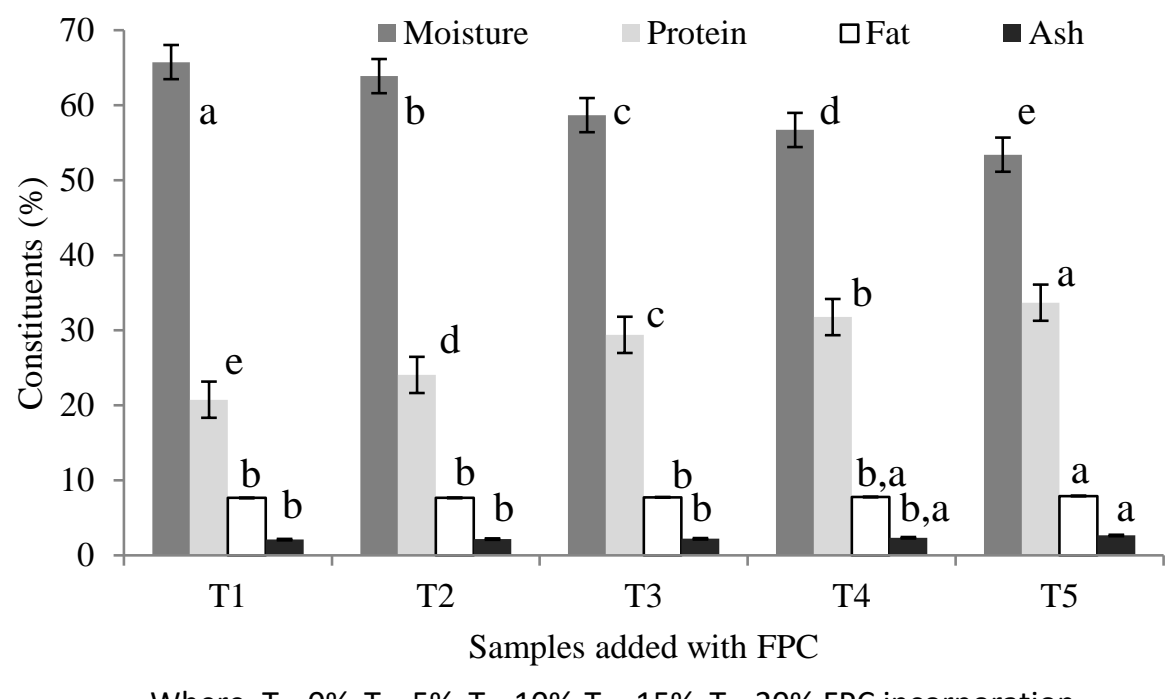

Figure 2. Proximate composition for fish finger incorporated with FPC

Values with different letters within the samples are significantly different at $\mathrm{P}<0.05$ by LSD

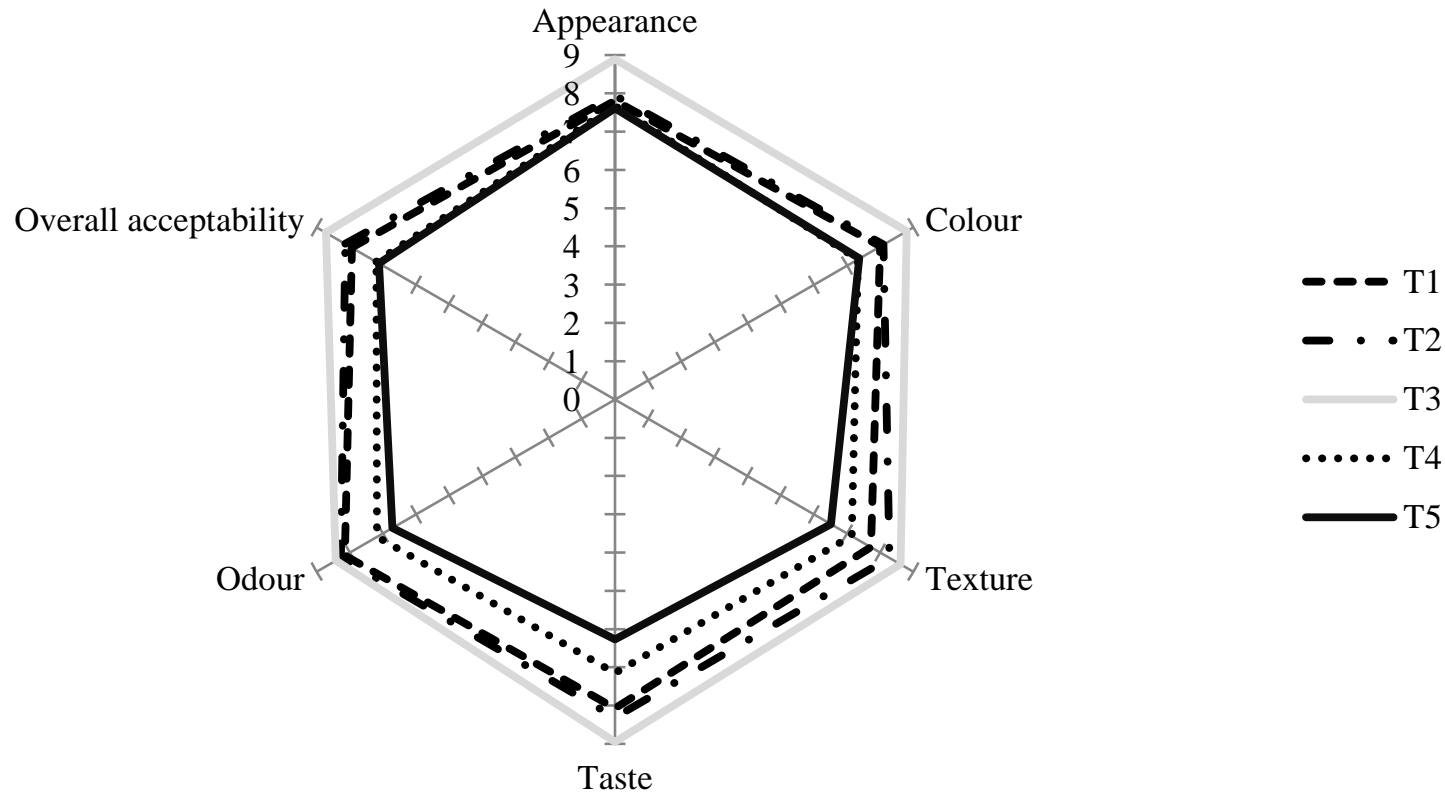

Where, $\mathrm{T}_{1=} 0 \%, \mathrm{~T}_{2=}, 5 \%, \mathrm{~T}_{3=} 10 \%, \mathrm{~T}_{4}=15 \%, \mathrm{~T}_{5}=20 \% \mathrm{FPC}$ incorporation

Figure 3. Sensory score for fish finger incorporated with FPC 
are presented in Figure 4. The $\mathrm{pH}$ of FPC incorporated fish fingers decreased significantly $(P<0.05)$ during storage. The $\mathrm{pH}$ value is related to the post-mortem evolution of fish, influencing the freshness and correlating to bacterial spoilage. A decline in $\mathrm{pH}$ of the product might be a result of oxygen consumption by aerobic microorganisms and releasing $\mathrm{CO}_{2}$. Similar results were reported for change in the $\mathrm{pH}$ of fish fingers made from Rohu (Labeo rohita) and Prussian carp (Carrassius gibelio) (Praneetha et al., 2015). Peroxide value (PV) indicates primary oxidation products responsible for the deterioration of fish during storage. Özyurt et al., (2011) suggested that lipid oxidation products in foods are results of heat treatment. The PV values of FPC incorporated fish fingers significantly $(\mathrm{P}<0.05)$ increased from $2.85 \mathrm{meqO}_{2} / \mathrm{kg}$ in fresh sample to 6.14 meq $\mathrm{O}_{2} / \mathrm{kg}$ during the 15 days storage period. A similar increasing trend was observed in the enrobed product prepared from anchovy during storage (Xavier et al., 2018). The formation of FFA is associated with enzymatic hydrolysis of esterified lipids (Hwang and Regenstein, 1993). Free fatty acid (FFA) of the Fish finger significantly $(P<0.05)$ increased from 0.33 to $0.97 \%$ of oleic acid during refrigerated storage. A similar trend was also observed during refrigerated studies of fish fingers from Rohu (Labeo rohita) (Vanitha et al., 2015; Praneetha et al., 2015). Total volatile basic nitrogen (TVB-N) and Trimethylamine nitrogen (TMA-N) are the products of microbial activity and decomposition by enzymatic action, often used as an index determining shelf life of fish and fish products. TVB-N and TMA-N values significantly $(P<0.05)$ increased during the storage from 1.51 to $5.16 \mathrm{mg} / 100 \mathrm{~g}$ and 1.34 to 4.86 $\mathrm{mg} / 100 \mathrm{~g}$, respectively. These values are well below the prescribed permissible limits of TVB-N (30 mg/100g) and TMA-N (10 mg/100g) through the study (EEC, 1995). Similar trends were reported in shrimp and fish fingers (Cakli et al., 2005).

Biochemical changes suggested a strong linear correlation during storage as shown in Figure 4. $\mathrm{pH}\left(\mathrm{R}^{2}=\right.$ $0.9956), P V\left(R^{2}=0.9658\right)$, FFA $\left(R^{2}=0.9883\right)$, TVB- $N\left(R^{2}=\right.$ $0.9782)$ and TMA-N $\left(R^{2}=0.9821\right)$.

\section{Effect of Storage on Organoleptic Quality of Fish Fingers}

Organoleptic quality is best method to judge market acceptability of product during storage The organoleptic quality of fish finger incorporated with $10 \%$ FPC was evaluated on sensory parameters i.e. appearance, color, texture, taste, odor and overall acceptability during the storage period (Table 2). The sensory scores significantly $(\mathrm{P}<0.05)$ declined during the storage period. The results of the organoleptic analysis indicated that fish fingers incorporated with $10 \%$ FPC were acceptable up to 11 days of storage and after 11 days it became unacceptable. These results are also supported by biochemical analysis. Similar findings for different fish products were reported by (Praneetha et al., 2015; Rathod and Pagarkar, 2013).

A linear negative correlation $\left(R^{2}<0.8451\right)$ for sensory quality changes over the storage period suggesting the shelf life of the product to be 11 days.

\section{Effect of Storage on Microbial Quality of Fish Fingers}

Total palate Count (TPC) is a shelf-life indicator, whereas other organisms (i.e. Escherichia coli, Staphylococcus aureus, and Salmonella) are pathogenic organisms. The TPC of freshly prepared FPC incorporated fish finger was $4.05 \times 10^{2} \mathrm{cfu} / \mathrm{g}$ (Log. 2.60), indicating hygienic processing conditions. During 15 days storage period TPC significantly $(P<0.05)$ increased Figure 4 with an $R^{2}$ value of 0.9705 , these values are below the maximum TPC limits prescribed by the International Commission on Microbiological Specification for Food (ICMSF, 1978). Pathogenic bacteria like, Staphylococcus aureus, Salmonella, and Escherichia coli were not detected in fish fingers during the entire storage period. Cakli et al., (2005) reported the Log TPC values of sardine, whiting and pike perch fingers to be in the range of 3 to 5. Praneetha et al., (2015) observed an increase from the initial count of $5.68 \times 10^{2} \mathrm{cfu} / \mathrm{g}$ to $1.72 \times 10^{5} \mathrm{cfu} / \mathrm{g}$ in Rohu fish fingers during storage.

Table 2. Sensory quality changes of Fish finger during storage*

\begin{tabular}{|c|c|c|c|c|c|c|}
\hline \multirow{2}{*}{ Storage Period (Days) } & \multicolumn{6}{|c|}{ Sensory Score } \\
\hline & Appearance & Colour & Texture & Taste & Odour & Overall acceptability \\
\hline 0 & $8.90 \pm 0.15^{a}$ & $8.82 \pm 0.19^{a}$ & $8.58 \pm 0.13^{a}$ & $8.96 \pm 0.14^{a}$ & $8.44 \pm 0.16^{a}$ & $8.72 \pm 0.19^{a}$ \\
\hline 1 & $8.60 \pm 0.09^{b}$ & $8.65 \pm 0.15^{a}$ & $8.43 \pm 0.19^{b}$ & $8.50 \pm 0.23^{b}$ & $8.40 \pm 0.19^{a, b}$ & $8.52 \pm 0.25^{\mathrm{a}, \mathrm{b}}$ \\
\hline 3 & $8.32 \pm 0.14^{c}$ & $8.06 \pm 0.22^{b}$ & $8.21 \pm 0.08^{c}$ & $8.13 \pm 0.25^{c}$ & $8.32 \pm 0.10^{\mathrm{b}}$ & $8.30 \pm 0.23^{b}$ \\
\hline 5 & $8.01 \pm 0.20^{d}$ & $7.92 \pm 0.19^{c, d}$ & $8.01 \pm 0.11^{\mathrm{d}, \mathrm{e}}$ & $8.05 \pm 0.21^{\mathrm{d}, \mathrm{e}}$ & $8.20 \pm 0.24^{b, c}$ & $8.05 \pm 0.25^{c}$ \\
\hline 7 & $7.86 \pm 0.17^{\mathrm{d}, \mathrm{e}}$ & $7.78 \pm 0.15^{d}$ & $7.84 \pm 0.20^{\mathrm{e}}$ & $7.98 \pm 0.20^{\mathrm{e}}$ & $7.65 \pm 0.19^{c}$ & $7.70 \pm 0.19^{d}$ \\
\hline 9 & $7.20 \pm 0.28^{e}$ & $7.41 \pm 0.20^{\mathrm{e}}$ & $7.22 \pm 0.25^{f}$ & $7.30 \pm 0.21^{f}$ & $7.11 \pm 0.17^{d}$ & $7.25 \pm 0.29^{e}$ \\
\hline 11 & $5.93 \pm 0.27^{f}$ & $5.79 \pm 0.16^{f}$ & $5.88 \pm 0.25^{g}$ & $5.74 \pm 0.17 \mathrm{~g}$ & $5.55 \pm 0.29 \mathrm{e}$ & $5.72 \pm 0.19^{f}$ \\
\hline 13 & $3.64 \pm 0.23^{g}$ & $3.78 \pm 0.20^{g}$ & $3.84 \pm 0.20^{h}$ & $3.48 \pm 0.21^{h}$ & $3.68 \pm 0.28^{f}$ & $3.62 \pm 0.14^{\mathrm{g}}$ \\
\hline 15 & $2.18 \pm 0.36^{h}$ & $2.90 \pm 0.25^{h}$ & $2.86 \pm .0 .11^{i}$ & $2.99 \pm 0.29 i$ & $2.32 \pm 0.24 \mathrm{~g}$ & $2.74 \pm 0.21^{\mathrm{h}}$ \\
\hline $\mathrm{R}^{2}$ & 0.8384 & 0.8455 & 0.8285 & 0.841 & 0.814 & 0.8451 \\
\hline
\end{tabular}

*Each value is represented as the mean \pm SD of $n=10$.

Values with different letters within the same column are significantly different at $\mathrm{P}<0.05$ by LSD 

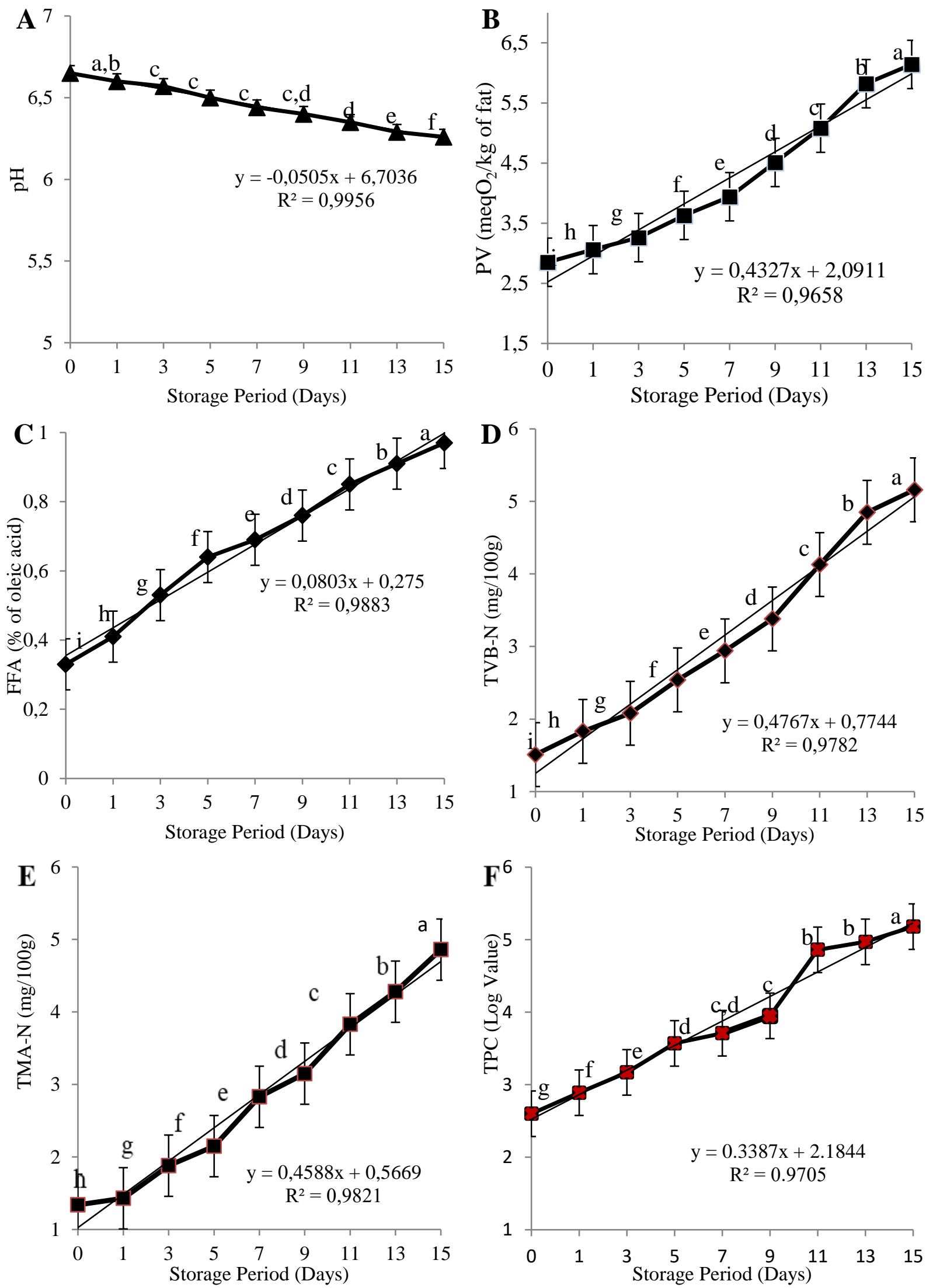

Figure 4. Effect of storage on biochemical and microbiological parameters of Fish finger (A-Changes in pH, B- Changes in PV, CChanges in FFA, D-Changes in TVB-N, E-Changes in TMA-N and F- Changes in TPC during storage) 


\section{Conclusion}

The result proved that FPC with superior proximate and functional qualities can be extracted from Pink perch fish by employing isopropyl alcohol solvent by the Canadian method. The FPC when incorporated in different proportions i.e. 0 to $20 \%$ in fish fingers formulation, the incorporation at $10 \%$ was most acceptable with significantly higher protein content than the control sample. Product evaluated for biochemical, microbial and sensory quality suggesting the product was 11 days. Results conclude FPC can be extracted from low-cost fish and can used for value addition.

\section{References}

AOAC, (1995). Official Methods of Analysis of Association Of Official Analytical Chemist, 16th Ed., Vol. II, AOAC, Arlington, VA.

AOAC. (2005). Official methods of analysis of the Association of Official Analytical Chemists International, $18^{\text {th }}$ edition, In: Horwitz, W. (Ed.), Washington D. C.

Beatty, S.A., and Gibbons, N.E. (1936). Studies of fish Spoilage. The origin of trimethylamine produced during the spoilage of cod muscle press juice. J Fisheries Board of Canada 4(2): 63-68.

Bragadottir, M., Reynisson, E., Porarinsdottir, K.A., and Arason, S. (2007). Stability of fish powder made from saithe (Pollachius virens) as measured by lipid oxidation and functional properties. J Aquatic Food Prod Technol 16(1): 115-136.

Butt, M.S., and Batool, R. (2010). Nutritional and functional properties of some promising legumes protein isolates. Pak J Nut 9(4): 373-379.

Cakli, S., Taskaya, L., Kisla, D., Çelik, U., Ataman, C.A., Cadun, A., and Maleki, R.H. (2005). Production and quality of fish fingers from different fish species. Eur Food Res Technol 220(5-6): 526-530.

Cercel, F., Burluc, R.M., and Alexe, P. (2016). Nutritional effects of added fish proteins in wheat flour bread. Agriculture and Agri Sci Procedia 10: 244-249.

Chari, S.T., and Sreenivasan, A. (1980). Protein concentrates from shark. Fishery Technol 17(2): 115-117.

Cho, S.H., Jahncke, M.L., Chin, K.B., and Eun, J.B. (2006). The effect of processing condition on the properties condition on the properties of gelatin from Skate (Raja kenojei) skins. Food Hydrocolloid, 20: 810-816.

Desai, A., Brennan, M.A., and Brennan, C.S. (2018). The effect of semolina replacement with protein powder from fish (Pseudophycis bachus) on the physicochemical characteristics of pasta. LWT-Food Sci Technol 89: 52-57.

Diniz, F.M., and Martin, A.M. (1997). Effects of the extent of enzymatic hydrolysis on the functional properties of Shark protein hydrolysate. LWT-Food Sci Technol. 30: 266-272.

EEC. (1995). Decision 95/149/EC. Total volatile basic nitrogen TVBN limit values for certain categories of fishery products and specifying the analysis method to be used. Official J 97: 84-87.

FAO. (2006). Fish Protein Concentrate, fish flour, fish hydrolyzate, animal feed resource information system, available: https://www.fao.org.
Govindan, T.K. (1985). Fish processing technology, pp. 218220, Oxford and IBH Publishing Co. Pvt. Ltd., New Delhi, India.

Halim, N. R. A., Yusof, H. M., and Sarbon, N. M. (2016). Functional and bioactive properties of fish protein hydolysates and peptides: a comprehensive review. Trends in Food Science \& Technology, 51, 24-33.

Hassan, M. A., Deepitha, R. P., Xavier, K. M., Gupta, S., Nayak, B. B., and Balange, A. K. (2018). Evaluation of the Properties of Spray Dried Visceral Protein Hydrolysate from Pangasianodon hypophthalmus (Sauvage, 1978) Extracted by Enzymatic and Chemical Methods. Waste and Biomass Valorization, 1-12.

Hoyle, N.T., and Merritt, J.H. (1994). Quality of fish protein hydrolysate from herring (Clupea harengus). J Food Sci 59: 76-79.

Huda, N., Aminah, A., and Babji, A.S. (2000). Effects of cryoprotectants on functional properties of dried lizardfish (Saurida tumbil) surimi. Malaysian Applied Bio 29(1\&2): 9- 16

Hwang, K.T., and Regenstein, J.M. (1993). Characteristics of mackerel mince lipid hydrolysis. J Food Sci 58(1): 79-83.

Ibrahim, S.M. (2009). Evaluation of production and quality of salt-biscuits supplemented with fish protein concentrate. World J Dairy Food Sci 4(1): 28-31.

ICMSF (1978). Microorganisms in foods. The International Commission on Microbiological Specifications for Foods. Vol. 1 Toronto, Canada.

Miller, R., and Goninger, H.S. (1976). Functional properties of enzyme modified acylated fish protein derivatives. $J$ Food Sci 41(2): 268-272.

Naqash, S. Y., and Nazeer, R. A. (2013). Antioxidant and functional properties of protein hydrolysates from pink perch (Nemipterus japonicus) muscle. Journal of food science and technology, 50(5), 972-978.

Özyurt, G., Özkütük, A.S., and Polat, A. (2011). Capability of the Rosemary (Rosmarinus officinalis) extract on the oxidative stability of cooked sea bream (Sparus aurata) during frozen storage.J für Verbraucherschutz und Lebensmittelsicherheit, 6(2): 167-174.

Pagarkar, A.U., Rathod, N.B., Baug, T.E., Pawar, P.P., and Desai, A.S. (2012). Standardisation of batter used for preparation of Pangasius (Pangasianodon hypophthalmus) cutlet. Aisan J Microbiol Biotech Env Sci 14 (4): 493-496.

Pawar, P. P., Pagarkar, A. U., and Rathod, N. B. (2020). Effect of chilled storage on quality characteristics of battered and breaded snack product from large sized Catla (Catla catla). Journal of Food Science and Technology, 1-8. DOI 10.1007/s13197-019-04028-6

Praneetha, S.S., Dhanapal, K., Reddy, G.V.S., and Balasubramanian, A. (2015). Development of fish finger from Rohu (Labeo rohita) and its quality evaluation during refrigerated storage condition. Int J Sci Env Technol 4:1457-1468.

Rathod, N., and Pagarkar, A. (2013). Biochemical and sensory quality changes of fish cutlets, made from Pangasius fish (Pangasianodon hypophthalmus), during storage in refrigerated display unit at- 15 to- $18{ }^{\circ} \mathrm{C}$. Int J Food Agric Vet Sci 3(1): 1-8.

Rathod, N. B., Ranveer, R. C., Benjakul, S., Kim, S. K., Pagarkar, A. U., Patange, S., \& Ozogul, F. (2021). Recent developments of natural antimicrobials and antioxidants on fish and fishery food products. Comprehensive 
Reviews in Food Science and Food Safety. 20(4): 41824210.

Sathivel, S., Bechtel, P.J., Babbitt, J., Smiley, S., Crapo, C., Reppond, K.D., and Prinyawiwatkul, W. (2003). Biochemical and functional properties of herring (Clupea harengus) byproduct hydrolysates. J Food Sci 68(7): 2196-2200.

Shaviklo, G.R., Thorkelsson, G., Rafipour, F., and Sigurgisladottir, S. (2011). Quality and storage stability of extruded puffed corn fish snacks during 6 month storage at ambient temperature. J Sci Food and Agric 91(5): 886893.

Shaviklo, G.R., Thorkelsson, G., Arason, S., and Sveinsdottir, K. (2012). Characteristics of freeze-dried fish protein isolated from saithe (Pollachius virens).J Food $\mathrm{Sci}$ Technol 49(3): 309-318.

Sikorski, Z. E., Naczk, M., and Toledo, R. T. (1981). Modification of technological properties of fish protein concentrates. Critical Reviews in Food Science \& Nutrition, 14(3), 201-230.

Snedecor, G.W., and Cochran, W.G. (1967). In: Statistical methods, Sixth ed. Oxford and IBH CO., New Delhi, 593 pp.
Vanitha, M., Dhanapal, K., and Reddy, G.V.S. (2015). Quality changes in fish burger from Catla (Catla catla) during refrigerated storage. J Food Sci Technol 52(3): 17661771.

Vanitha, M. (2011). Development of Value Added Products from Catla (Catla Catla) and It's Quality Evaluation. A Doctoral Dissertation of Sri Venkateswara Veterinary University, Tirupati-517502, Andhra Pradesh.

Xavier, M., Piyadarshini, B., Ninan, G., Zynudheen, A.A., Mathew, P.T., Nair, K.G.R and Joseph, A.C. (2018). Enrobed Snack Product from Devis's Anchovy (Stolephorus commersonnii) and its Quality Evaluation during Frozen Storage.J Aquatic Food Prod Technol 27(7): 859-867.

Yoon, I. S., Lee, G. W., Kang, S. I., Park, S. Y., Lee, J. S., Kim, J. S., and Heu, M. S. (2018). Chemical composition and functional properties of roe concentrates from skipjack tuna (Katsuwonus pelamis) by cook-dried process. Food science \& nutrition, 6(5), 1276-1286.

Yu, J., Ahmedna, M., and Goktepe, I. (2007). Peanut protein concentrates: Production and functional properties as affected by processing. Food Chem 103(1): 121-129.r 